\title{
Clinical, economic, and humanistic burden of needlestick injuries in healthcare workers
}

This article was published in the following Dove Press journal:

Medical Devices: Evidence and Research

29 September 2017

Number of times this article has been viewed

\author{
Catherine E Cooke' \\ Jennifer M Stephens ${ }^{2}$ \\ 'Department of Pharmacy Practice \& \\ Science, University of Maryland \\ School of Pharmacy, Baltimore, MD, \\ ${ }^{2}$ Pharmerit International, Bethesda, \\ MD, USA
}

Introduction: Needlestick injuries (NSIs) from a contaminated needle put healthcare workers (HCWs) at risk of becoming infected with a blood-borne virus and suffering serious short- and long-term medical consequences. Hypodermic injections using disposable syringes and needles are the most frequent cause of NSIs.

Objective: To perform a systematic literature review on NSI and active safety-engineered devices for hypodermic injection.

Methods: MEDLINE, EMBASE, and COCHRANE databases were searched for studies that evaluated the clinical, economic, or humanistic outcomes of NSI or active safety-engineered devices.

Results: NSIs have been reported by $14.9 \%-69.4 \%$ of HCWs with the wide range due to differences in countries, settings, and methodologies used to determine rates. Exposure to contaminated sharps is responsible for $37 \%-39 \%$ of the worldwide cases of hepatitis B and C infections in HCWs. HCWs may experience serious emotional effects and mental health disorders after a NSI, resulting in work loss and post-traumatic stress disorder. In 2015 International US\$ (IntUS\$), the average cost of a NSI was IntUS\$747 (range IntUS\$199-1,691). Hypodermic injections, the most frequent cause of NSI, are responsible for $32 \%-36 \%$ of NSIs. The use of safety devices that cover the needle-tip after hypodermic injection lowers the risk of NSI per HCW by $43.4 \%-100 \%$ compared to conventional devices. The economic value of converting to safety injective devices shows net savings, favorable budget impact, and overall cost-effectiveness.

Conclusion: The clinical, economic, and humanistic burden is substantial for HCWs who experience a NSI. Safety-engineered devices for hypodermic injection demonstrate value by reducing NSI risk, and the associated direct and indirect costs, psychological stress on HCWs, and occupational blood-borne viral infection risk.

Keywords: injections, occupational injuries, blood-borne pathogens, healthcare personnel safety, safety-engineered devices

\section{Introduction}

Needlestick injury (NSI) is an accidental percutaneous piercing wound caused by a contaminated sharps instrument, usually a hollow-bore needle from a syringe, and is one of the most frequent routes of transmission in occupationally acquired bloodborne infections. ${ }^{1}$ More than 20 blood-borne infections may be transmitted by NSI. In the most severe cases, the transmission of human immunodeficiency virus (HIV), hepatitis $B$ virus (HBV), and hepatitis $\mathrm{C}$ virus (HCV) may severely impair quality of life and reduce life expectancy, while incurring substantial costs, especially in the long term. ${ }^{2-6}$
Correspondence: Catherine E Cooke University of Maryland School of Pharmacy, 20 N. Pine Street, Baltimore, MD 2I20I, USA

Tel + I 410706 |45|

Email cCooke@rx.umaryland.edu 
The World Health Organization (WHO) recommends the use of safety injection devices and instructs governments to transition to their exclusive use by $2020 .^{7}$ The USA, Canada, Brazil, Taiwan, United Kingdom (UK) and European Union (EU) countries have enacted legislation requiring the use of safety injection devices. Despite an increased awareness and legislation in some countries, NSIs and their serious consequences still occur. Since NSIs occur most often during hypodermic injections, this review sought to understand the burden of NSI by conducting a systematic literature review on NSI and active safety-engineered devices for hypodermic injection.

\section{Methods}

Literature searches were conducted in PubMed and EMBASE to identify outcomes - evidence of the burden of NSI and impact of safety needles with active mechanisms for hypodermic injection, as there are no currently marketed passive mechanism devices for hypodermic injection (Table S1). Search terms and combinations that were used in PubMed included needlestick injury, accidental needlestick, safety needles, safety-engineered needles, engineered sharps, needleless systems, needles, safety device, viral infections, quality of life, patient satisfaction, worry, distress, resource utilization, resource use, cost, budget impact, indirect cost, work loss, work policy, productivity, policy, public policy, and other related terms. Additional limits applied to each search included: humans, English language only, and publication date within past 10 years.

These searches identified 982 unique references. Inclusion criteria were studies that reported policy or clinical, economic, or humanistic outcomes of NSI or safety injection devices on healthcare workers (HCWs) in healthcare settings. Studies were defined as health economic or budget impact studies, real-world observational studies, comparative effectiveness studies, clinical trials, and case reports with an adequate sample size $(n=20)$. Articles were excluded if the full text was not available, or if the article did not include hypodermic injections. Additional searches were conducted using Google and Google Scholar. In total, 155 references were selected after title/abstract screening, with 69 selected after full text review, and discussed in this review article.

\section{Results}

\section{Legislation}

As of 2017, several countries have enacted legislation regarding NSI and safety-engineered devices including the USA, Canada $^{8}$, UK, EU countries, ${ }^{9}$ Brazil, ${ }^{10}$ and Taiwan. ${ }^{11}$

The legislation has increased the use of safety-engineered devices, even in countries where these devices were available prior to the legislation. In the USA, voluntary adoption of safety devices without mandated legislation was ineffective in producing a large-scale reduction in NSI rates. ${ }^{12} \mathrm{~A}$ significant 38\% drop in hospital NSI rates occurred only after the Needlestick Safety Prevention Act (NSPA) was enacted and safety devices became the predominant technology in healthcare settings. ${ }^{12,13}$ Compliance with mandatory safetyengineered device legislation has been high in US hospital settings. However, HCWs in non-hospital settings (i.e., clinics, private offices, long-term care facilities, and free-standing laboratories) account for $\sim 60 \%$ of the healthcare workforce, but have $25 \%-35 \%$ lower adoption rates of safety-engineered devices than hospitals. ${ }^{13}$ In the UK, since the passage of the EU Council Directive 2010/32/EU and the Health and Safety (Sharps Instruments in Healthcare) Regulations of 2013, the majority of National Health Service (NHS) trusts instruct their staff to use safety devices whenever possible. However, one-third of the NHS trusts have failed to implement safe sharps practices. ${ }^{14}$

Often, legislation without enforcement has less significant impact on the implementation of safety devices in healthcare settings. In Brazil, adoption of safety devices has been slower as there are gaps in the monitoring of the adoption of safe practices, mainly related to preventing and controlling occupational accidents. ${ }^{10}$

\section{Clinical burden of NSIs}

Rates of NSI in the hospital differ by country, use of safety devices, and methodologies (including potential underreporting) used. Studies report a wide range from $14.9 \%$ to $69.4 \%$ of HCWs who have experienced a NSI, and 3.2-24.7 NSIs per 100 occupied hospital beds (Table 1). ${ }^{15-18}$

Hypodermic (i.e., intramuscular, subcutaneous, or intradermal) injections using disposable syringes and needles are the most frequent cause of NSIs worldwide. ${ }^{18-20}$ In US hospitals, $35.4 \%$ of all percutaneous injuries are due to disposable syringes (Figure 1), with similar rates reported in other parts of the world - 32\% in 13 European countries and Russia and 34.6\% in Saudi Arabia. ${ }^{18-20}$

Literature that relies solely on officially reported NSIs may underestimate NSI rates. The Centers for Disease Control (CDC) estimates that about half of sharps injuries in the US go unreported. ${ }^{21}$ In Sweden, $26.9 \%$ of HCWs with a NSI in the preceding year did not report any or all of their NSI events, even though $80.1 \%$ of respondents knew to contact occupational health services. ${ }^{22}$ There are multiple reasons that HCWs do not report NSIs: presumption that the risk of disease transmission is low, lack of knowledge of systems 
Table I Representative NSI rates by country

\begin{tabular}{|c|c|c|c|}
\hline Country & Rate of NSI & Site & Time frame \\
\hline Australia $^{57}$ & 2.86 percutaneous exposures per 100 FTE staff & 20 Queensland public hospitals & $2004-2011$ \\
\hline Brazil $^{58}$ & $\begin{array}{l}386 \text { exposures to biological material recorded } \\
\text { among } 1,736 \text { nursing staff }\end{array}$ & Teaching hospital in São Paulo & $2003-2009$ \\
\hline China $^{59}$ & $64.9 \%$ of nurses experienced NSI within past year & $\begin{array}{l}\text { Teaching hospital in Nanjing, Jiangsu } \\
\text { Province }\end{array}$ & April 2012 \\
\hline Egypt $^{16}$ & $\begin{array}{l}69.4 \% \text { of } \mathrm{HCW} \text { seported at least one NSI in their } \\
\text { lifetime and } 35.6 \% \text { reported an injury during the } \\
\text { previous } 3 \text { months; mean number of injuries during } \\
\text { past } 3 \text { months was } 1.23 \text {, equating to the rate of } 4.9 \\
\text { NSI per HCW annually }\end{array}$ & $\begin{array}{l}\text { Ninety-eight healthcare facilities in one } \\
\text { governorate in the Nile Delta and one } \\
\text { governorate in Upper Egypt }\end{array}$ & $\begin{array}{l}\text { Three months prior to date } \\
\text { of interview (interview date } \\
\text { unknown) }\end{array}$ \\
\hline France ${ }^{60}$ & $\begin{array}{l}6.3 \text { blood and body fluid exposures per } 100 \text { beds } \\
\text { with most frequent being NSls }\end{array}$ & National surveillance of French hospitals & 2012 \\
\hline $\mid$ taly $y^{61}$ & $\begin{array}{l}53 \% \text { of nurses and nursing students reported having } \\
\text { had at least one injury during their career }\end{array}$ & University hospital of Ferrara & $2002-2012$ \\
\hline Netherlands ${ }^{62}$ & $0.5 \mathrm{NSI} /$ day $\mathrm{I}, 053$ total $/ 8$ years & $\begin{array}{l}\text { Academic Medical Centre in Amsterdam } \\
\text { (unknown number of beds or HCWs) }\end{array}$ & $2003-2010$ \\
\hline Saudi Arabia ${ }^{17}$ & 3.2 NSIs per 100 occupied hospital beds & $\begin{array}{l}\text { Fifty-two Ministry of Health Hospitals via } \\
\text { EPINet }\end{array}$ & January 2012-December 2012 \\
\hline South Africa ${ }^{15}$ & $\begin{array}{l}14.9 \% \text { of HCWs reported having a NSI or blood } \\
\text { and body fluid exposure in past } 6 \text { months }\end{array}$ & Small Rural Hospital in Thabo-Mofutsanyana & $\begin{array}{l}\text { Survey date unknown, but } \\
\text { estimated between } 2010 \text { and } \\
2014\end{array}$ \\
\hline South Korea ${ }^{63}$ & 2.62 cases per $100 \mathrm{HCW}$-years & Teaching hospital; $94 \%$ of cases were NSI & January 1992-December 200I \\
\hline Taiwan $^{64}$ & $\begin{array}{l}8,058 \text { percutaneous injuries per } 129,548 \text { hospital } \\
\text { beds annually }(\sim 6 \text { per } 100 \text { beds) } 8,100 \text { percutaneous } \\
\text { injuries per } 180,000 \text { HCW FTE annually }\end{array}$ & $\begin{array}{l}\text { National estimates ( } 420 \text { accredited hospitals } \\
\text { enrolled in a surveillance program to track } \\
\text { blood exposure incidents) }\end{array}$ & Annually \\
\hline $\mathrm{UK}^{65}$ & $\begin{array}{l}48 \% \text { of nurses had NSI in career with } 10 \% \text { sustaining } \\
\text { an injury in past year }\end{array}$ & $\begin{array}{l}\text { Randomly selected nurse members of Royal } \\
\text { College of Nursing }\end{array}$ & September 2008 \\
\hline USA $^{18}$ & 24.7 injuries per 100 average daily census & $\begin{array}{l}\text { Geographically diverse hospitals across } \\
\text { the USA }\end{array}$ & January 2014-December 2014 \\
\hline
\end{tabular}

Abbreviations: EPINet, exposure prevention information network; FTE, full-time equivalent; HCWs, healthcare workers; NSls, needlestick injuries.

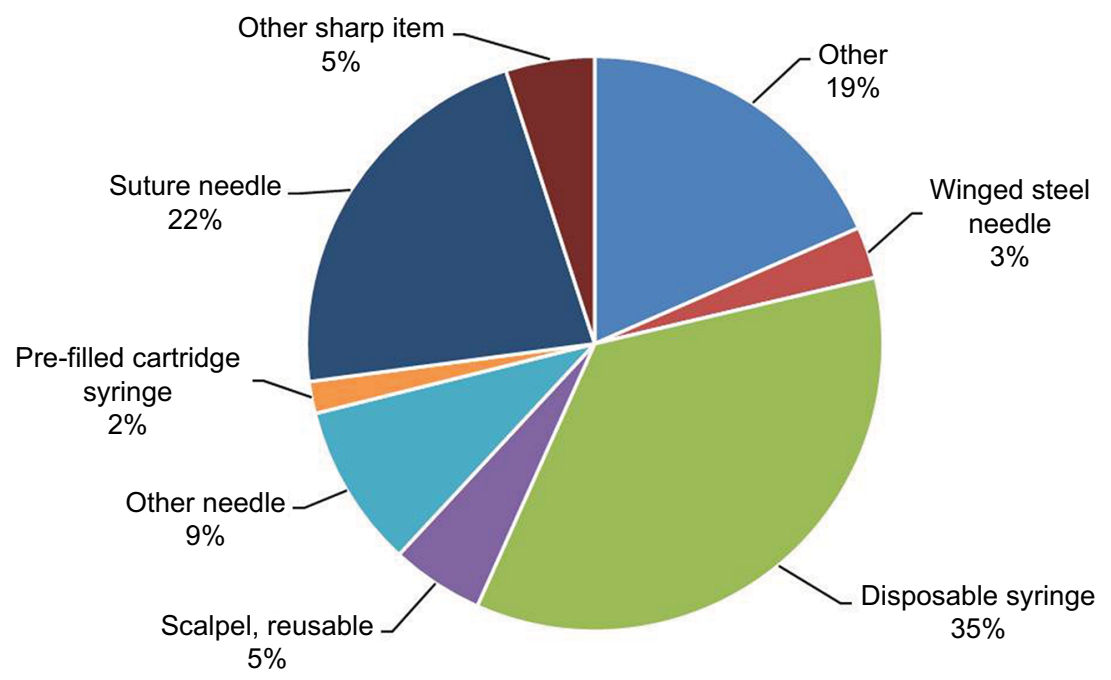

Figure I Frequency of NSIs by device, $\mathrm{n}=557$.

Notes: Data from EPINet. ${ }^{18}$

Abbreviations: EPINet, exposure prevention information network; NSIs, needlestick injuries.

for reporting, lack of knowledge of the importance of reporting NSIs, complicated and unclear reporting protocols, and HCW belief that an injury may reflect poorly on their practice standards. ${ }^{2,23}$

\section{NSI risk factors}

NSIs appear to be repetitive, with $73 \%$ of HCWs who sustained a NSI noting a previous NSI. ${ }^{24}$ Risk factors associated with NSIs have been categorized into two groups: modifiable 


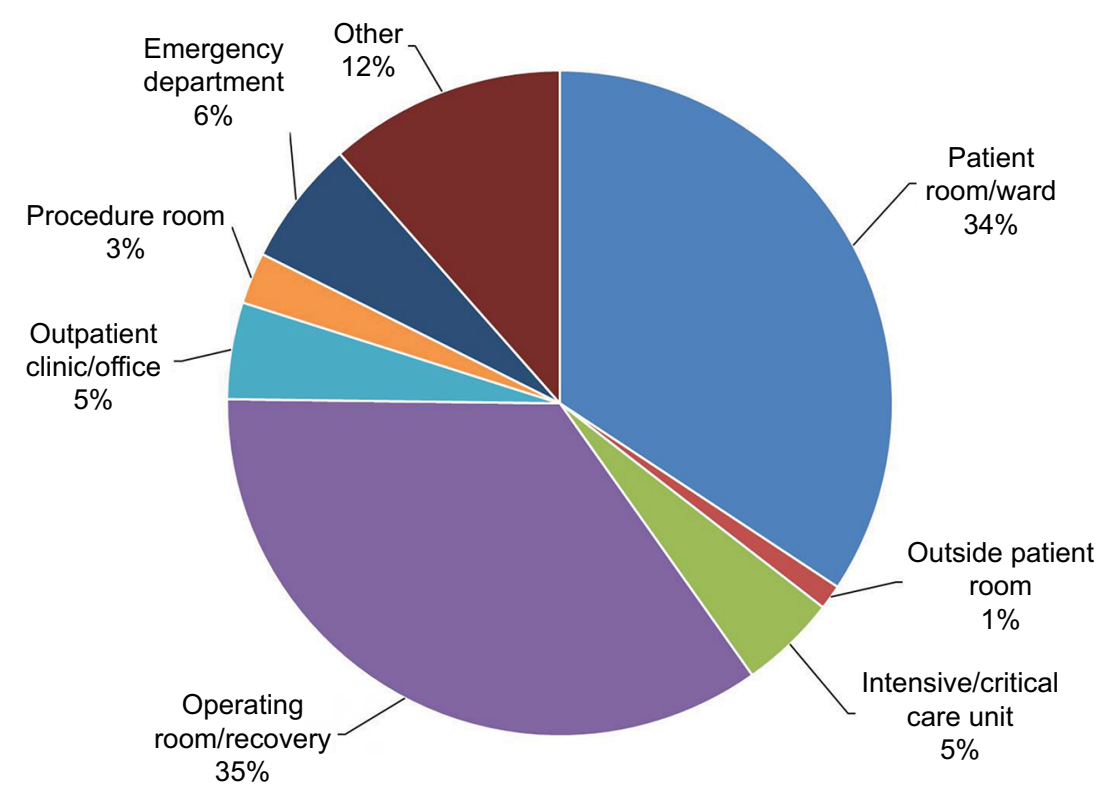

Figure 2 Work locations where reported sharps injuries occurred, $\mathrm{n}=592$.

Notes: Data from EPINet. ${ }^{18}$ The sum is $>100 \%$ due to rounding.

Abbreviation: EPINet, exposure prevention information network.

and non-modifiable. ${ }^{24,25}$ Non-modifiable risk factors for NSI are conditions that cannot be deliberately altered. HCWs with the highest rates of NSIs are women, nurses, and those aged 21-30 years. ${ }^{24,25}$ The prevalence of these demographic characteristics is associated with higher rates of needle use as the majority of HCWs who handle syringes are female nurses. ${ }^{24}$ Modifiable risk factors include hospital care setting, poor working environments such as long work hours, understaffing, and inadequate needle disposal procedures (e.g., 37\% of HCWs recapped the needle) and devices (e.g., lack of sharps containers). ${ }^{24,26}$ Mental and physical stress associated with excessive working hours are also believed to contribute to a higher NSI rate. ${ }^{24}$

The most common hospital care settings for NSIs are the general medical wards, the operating room, the emergency department (ED), and the intensive and critical care units. In the US, 35\% of sharps injuries occurred in the operating room, and $34.3 \%$ in patient rooms/wards (Figure 2). ${ }^{18}$ In Saudi Arabia, the highest rates of NSI occurred in the patient's room (31.4\%), followed by the ED (17.2\%), then the intensive and critical care units $(14.7 \%) .{ }^{19}$

HCWs in urban EDs face higher risk for sharps injuries compared to community EDs with rates of 20.3 versus 5.9 per 100,000 patient visits, respectively $(p<0.001) .{ }^{27}$ The environment in EDs is fast-paced and often unpredictable, in addition to often unknown source status, thus increasing the risk of NSIs and their consequences.

In the intensive care units (ICUs), there is additional concern as patients may be incapacitated and unable to consent to testing should a NSI occur. This concern is highlighted in a study which found that $62.6 \%$ of ICUs in England, Wales, and Northern Ireland had reported one or more NSIs to an $\mathrm{HCW}$ from an incapacitated patient. ${ }^{69}$ Of the 62 cases of NSIs, at least $25.8 \%$ of NSIs were from patients with bloodborne viruses, with $37.5 \%$ unaware of their positive status prior to ICU admission.

\section{Infection risk from NSI}

The risk of becoming infected with a blood-borne virus after NSI is highest for hepatitis B, followed by hepatitis C, and then HIV. For every 1,000 NSIs from an infected patient, 300 HCWs will become infected with HBV. For HCV and HIV, seroconversion rates are 30 per 1,000 and three per 1,000 , respectively. Since the prevalence of blood-borne pathogens such as HBV, HCV and HIV is higher in hospitalized patients, there is greater risk after NSI in this setting. ${ }^{29}$ Despite being unseen by the naked eye, blood remains on the needle after a hypodermic injection. ${ }^{30}$ Exposure to even minute quantities of blood from a NSI can result in serious disease, with transmission linked to hypodermic injection noted in developing nations. ${ }^{31}$

\section{Safety devices reduce NSI rates}

About $41 \%$ of NSIs from hollow-bore needles occur after the injection has been given: $19 \%$ occurring after use, but before disposal, and $22 \%$ occurring during, or after, disposal. ${ }^{32}$ With disposable syringe/needle use, the process of recapping alone is responsible for $11.1 \%$ of injuries. ${ }^{33} \mathrm{~A}$ systematic literature 
review on safety devices examined 17 articles, six of which included safety syringe/needle devices for hypodermic injection. ${ }^{34}$ Compared to conventional devices, safety syringes/ needles for hypodermic injection reduced the risk of NSIs by $43.4 \%-100 \%$. A more recently published systematic review and meta-analysis found nine studies on safety syringe/needle devices for subcutaneous, intramuscular, and intradermal injections. ${ }^{35}$ These hypodermic safety injection devices had a pooled relative risk of NSI of HCW of 0.54 (95\% CI 0.41-0.71).

Active safety devices for hypodermic injection include a safety sliding shield needle, a safety toppling shield needle, and a safety pivoting shield needle. An active device (Septodont Safety Plus) reduced avoidable NSIs in a dental school practice from an average of 11.8 to 0 injuries per 1,000,000 hours worked per year as compared with a control unit who reduced their frequency from 26 to 20 injuries per 1,000,000 hours worked. ${ }^{36}$ Studies in hospitals that reported the device name describe a one-handed, active manual activation device (BD SafetyGlide), activated by pushing a lever arm forward with a single finger stroke to cover needle tip, and a one-handed, active manual activation device (BD Eclipse) activated by pushing a hinged safety shield over the needle tip with a finger or thumb (Table 2). These studies found a significant reduction in NSIs of $64 \%-100 \%{ }^{37-39}$ In one of the studies, HCWs at a University Hospital in the UK completed questionnaires and noted that the BD SafetyGlide was "safe, usable and compatible with most clinical situations", and felt that this safety needle device "should be used for any procedure where a risk of exposure to blood and body fluids existed". ${ }^{37}$

Another study compared NSI rates from different device types, without specifying device names. ${ }^{70}$ Data from a French

Table 2 Studies reporting rates of NSI after implementation of named active safety devices in hospitals

\begin{tabular}{|c|c|c|}
\hline Study & Device type/name & NSI rate \\
\hline $\begin{array}{l}\text { Adams and } \\
\text { Elliott }^{37}\end{array}$ & $\begin{array}{l}\text { Safety sliding } \\
\text { shield needle (BD } \\
\text { SafetyGlide) }\end{array}$ & $\begin{array}{l}70 \% \text { reduction in NSls } \\
(p=0.045) \text { after introduction } \\
\text { of BD SafetyGlide }\end{array}$ \\
\hline Valls et $\mathrm{a}^{39}$ & $\begin{array}{l}\text { Safety pivoting shield } \\
\text { needle (BD Eclipse) }\end{array}$ & $\begin{array}{l}100 \% \text { reduction in NSIs } \\
\text { from hypodermic injections } \\
\text { (i.e., } 0 \mathrm{NSI} \text { after introduction } \\
\text { of BD Eclipse) }\end{array}$ \\
\hline $\begin{array}{l}\text { van der Molen } \\
\text { et al; }{ }^{38} \text { van der } \\
\text { Molen et } \mathrm{al}^{66}\end{array}$ & $\begin{array}{l}\text { Safety pivoting shield } \\
\text { needle (BD Eclipse) }\end{array}$ & $\begin{array}{l}64 \% \text { reduction in NSls after } \\
\text { introduction of BD Eclipse }\end{array}$ \\
\hline
\end{tabular}

Notes: BD SafetyGlide and BD Eclipse are both manufactured by Becton Dickinson, Franklin Lakes, NJ, USA.

Abbreviation: NSls, needlestick injuries. multicenter study reported the number $(95 \% \mathrm{CI})$ of NSIs per 100,000 hypodermic injection devices purchased was 5.20 (4.61-5.78) and 2.94 (2.35-3.53) for manually activated protective sliding shield and manually activated protective toppling shield, respectively. ${ }^{70}$

\section{Economic burden}

After a NSI occurs, there is substantial cost, which includes, 1) testing for infection in the injured worker and, if known, the patient on whom the needle/sharp had been used, 2) postexposure prophylaxis to prevent or manage potential bloodborne virus transmission, 3) short- and long-term treatment of chronic blood-borne viral infections that are transmitted to injured workers, 4) staff absence and replacement, 5) counseling for injured workers, and 6) legal consequences (litigation and compensation claims). ${ }^{23}$

Table 3 summarizes the published economic studies reporting cost of a NSI, national burden, or economic impact of safety needle programs. These studies addressed a mix of direct and indirect costs, national burden, and economic impact of safety needles. Cost of a NSI varies widely and depends on what types of costs are included, as well as the risk/source of the needlestick. For example, the US CDC cites estimates of the direct costs associated with the initial followup and treatment of HCWs who sustain a NSI ranging from US\$71 to US\$5,000, depending on the treatment. ${ }^{40}$ Some studies report that only some NSIs actually generated costs (e.g., $72.1 \%$ of NSIs in Korea), because of underreporting or cases with low-risk known sources.

In studies reporting both direct and indirect costs, the cost breakdown of NSI ranged from $44 \%$ to $77 \%$ direct costs and $23 \%$ to $56 \%$ indirect costs. ${ }^{3,23,41,42}$ Within direct costs, the top cost driver is prophylaxis medications after the NSI, and ranges from $54 \%$ to $96 \%$ of the average direct medical costs after NSI. In Korean hospitals the NSI direct costs by department were $54.5 \%$ pharmacy, $29.7 \%$ laboratory tests, $11.7 \%$ medical services, and $4.2 \%$ medical treatments. ${ }^{43}$

\section{Economic benefits of safety injection needles}

The current costs of safety needles are $\sim 2-3$ times the cost of non-safety needles. To gauge the impact of the use of safety needles on a hospital budget, studies have reported annual cost impact from a perspective important to healthcare administrators. ${ }^{42}$ An Australian study found that the annual cost increase due to the use of hypodermic safety needles was the equivalent of $\$ 14$ for each at-risk HCW or $\$ 2$ per occupied bed per day. ${ }^{42}$ Data from Spain show that the direct 
Table 3 Economic analyses of the cost of a NSI and impact of safety devices

\begin{tabular}{|c|c|c|}
\hline Reference & Country/Setting & Cost per NSI ${ }^{a}$ (mean) and other economic findings \\
\hline Mannocci et $a^{167}$ & $\begin{array}{l}\text { I4 studies in } \\
\text { eight countries }\end{array}$ & $\begin{array}{l}\text { IntUS } \$ 425 \text { (IntUS\$48-I,5I6) median direct cost; IntUS\$322 (IntUS\$I52-4I3) median indirect } \\
\text { cost, totaling Int } \$ 747 \text { (Int } \$ 199-1,69 \mid \text { [20I5]) using a combined calculation by converting costs to } \\
\text { international dollars across countries }\end{array}$ \\
\hline Oh et $\mathrm{al}^{43}$ & Republic of Korea & $\begin{array}{l}225,758 \text { Won (US } \$ 237) \text { direct costs }(54.5 \% \text { pharmacy, } 29.7 \% \text { laboratory tests, II.7\% medical services, } \\
4.2 \% \text { medical treatments). Thirty four hospitals reporting } 700 \text { NSIs were used to project a national } \\
\text { annual economic burden in Korea of } 844,587,577 \text { Won (US } \$ 884,385 \text { [2005-2006]) }\end{array}$ \\
\hline Hanmore et $\mathrm{a}^{23, \mathrm{~b}}$ & Belgium & $\begin{array}{l}€ 210-950 \text { direct costs }(2012) ; € 63-844 \text { indirect costs. Incidence-based budget impact model projected } \\
\text { an } 86 \% \text { reduction in NSls with safety injection devices. Positive net budget impact for a } 420 \text {-bed hospital } \\
\text { (i.e., savings) of } € 51,710 \text { over } 5 \text { years with switching to safety injection devices }\end{array}$ \\
\hline $\begin{array}{l}\text { Glenngård and } \\
\text { Persson }^{44, b}\end{array}$ & Sweden & $\begin{array}{l}€ 272 \text { (SEK } 2,5 / 3 \text { [2007]) direct costs. Projected } 80 \% \text { fewer NSIs from hollow-bore needles by } \\
\text { conversion to safety needles; resulted in a savings of } € 0.0 \text { I (SEK 0.07) per used needle for tests, } \\
\text { investigations, and treatment }\end{array}$ \\
\hline Trueman et $\mathrm{al}^{2}$ & UK & $\$ 550$ direct costs ( $£ 362[2005]) . £ 600,000 \mathrm{NHS}$ burden related to NSI with insulin administration \\
\hline Wittman et $\mathrm{a}^{29}$ & Germany & $€ 490$, with the hospital paying $€ 148$ of the cost (Working Party at Bergische University Wuppertal) \\
\hline Leigh et $\mathrm{al}^{3}$ & US & $\begin{array}{l}\$ 596 \text { ( } \$ 339 \text { direct medical costs and } \$ 257 \text { lost work productivity costs [2004]). Annual national US cost } \\
\text { of } \$ 188.5 \text { million (direct medical costs of } \$ 107.3 \text { million and indirect costs from lost-work productivity } \\
\text { of } \$ 81.3 \text { million) }\end{array}$ \\
\hline O'Malley et al ${ }^{68}$ & US & $\begin{array}{l}\$ 376(\$ 7 \mathrm{I}-860[2003]) \text { for exposure to source patient with unknown or negative infection status } \\
\text { ( } \mathrm{n}=19) \text {. } \$ 650(\$ 186-856) \text { for source patient infected with } \mathrm{HCV}(\mathrm{n}=4) \text { ) } \$ 2,456(\$ 907-4,838) \text { for } \\
\text { exposure to HIV-infected source patient, including co-infection with HBV or HCV }(n=19) \text {. Detailed } \\
\text { information was collected from four healthcare facilities on time spent on reporting, managing, and } \\
\text { following up the exposures; salaries (including benefits) for representative staff who sustained and } \\
\text { managed exposures; and costs (not charges) for laboratory testing of exposure sources and exposed } \\
\text { healthcare personnel, as well as any post-exposure prophylaxis taken by the exposed personnel }\end{array}$ \\
\hline Lee et $\mathrm{a}^{41, \mathrm{~b}}$ & $\begin{array}{l}\text { Survey USA and } \\
\text { OSHA report for } \\
\text { State of California }\end{array}$ & $\begin{array}{l}\text { Average cost of NSI per injured nurse was } \$ 259 \text { and average cost per NSI was } \$ 159 \text { (2004). Cost- } \\
\text { benefit analysis of safety needles in state hospitals would achieve a net annual statewide savings of } \$ 320 \\
\text { million in medical care costs }\end{array}$ \\
\hline
\end{tabular}

Notes: a Reported in US\$ unless otherwise specified. 'b Assessed cost savings of safety-needle conversion.

Abbreviations: HBV, hepatitis B virus; HCV, hepatitis C virus; HIV, human immunodeficiency virus; Int, international; NHS, National Health Service; NSI, needlestick injury; OSHA, Occupational Safety and Health Administration; SEK, Swedish Krona.

cost increase for hypodermic safety needles was $€ 0.021$ (US\$0.028) per patient in the ED. ${ }^{39}$

Although the acquisition costs of safety needles are greater than conventional needles, safety needles provide economic value based on the reduction in NSIs. In a Swedish study, direct medical costs resulting from 3,906 hollow-bore needle sharps injuries were found to be $€ 0.04$ (Swedish Krona [SEK] 0.34) per used needle. ${ }^{44}$ Using safety devices instead of conventional needles at all hospitals, primary care facilities, and outpatient clinics outside hospitals was found to save $€ 0.01$ (SEK 0.07) per used needle for tests, investigations, and treatment. The assumption was that $80 \%$ of hollowbore needle sharps injuries could be prevented, resulting in 3,125 fewer injuries. A review of the cost-effectiveness of safety devices in a study by Lee et al included data collected by California Occupational Safety and Health Administration (OSHA) ${ }^{45}$ Due to the rising rates of NSI, the state of California analyzed the cost-effectiveness of using safety-engineered devices to support pending legislation that would require stricter handling of syringes. The California OSHA reported that the implementation of safety needle devices would cost the state $\$ 124$ million. A cost savings of $\$ 228$ million and $\$ 216$ million would be realized with the elimination of new HIV and hepatitis cases, respectively. As a result, an annual savings of $\$ 320$ million in healthcare costs was projected. ${ }^{46}$ California OSHA found that the implementation of safety devices would produce savings much larger than the initial cost of using safety syringes.

In a dental school practice, the authors noted that the "reduction in cost of management of needlestick injuries including the psychological effects are significant" for hypodermic safety syringes. ${ }^{36}$

In Belgium, an economic model found that the decrease in the long-term costs due to NSIs offsets the acquisition costs of safety needles. ${ }^{23} \mathrm{~A}$ 5-year incidence-based budget impact model was developed from a 420-bed Belgian hospital inpatient perspective, comparing costs and outcomes with the use of safety devices and prior-used non-safety devices. The model included device acquisition costs and the costs of NSI management in blood collection, infusion, injection, and diabetes insulin administration. For injections, the average cost per conventional and safety injection device was $€ 0.014$ and 
$€ 0.046$, respectively, with an expected $86 \%$ reduction in NSI using safety injection devices. An increase in safety device acquisition costs was offset by savings through avoided NSIs. When switching to safety injection devices (including other safety devices beyond hypodermic injection), the net budget impact over 5 years showed a savings of $€ 51,710$. While a variety of sensitivity analyses and changes in model assumptions were performed, the results continued to demonstrate cost savings. The model was most sensitive to variation in the acquisition costs of safety devices, the rates of NSI associated with conventional devices, and the acquisition costs of conventional devices. $^{23}$

\section{Avoiding financial penalties due to non- compliance with regulatory requirements}

In the USA, OSHA enforces the requirements set forth by the NSPA. One of the requirements is that employers must consider and implement appropriate commercially available and effective safer medical devices designed to eliminate or minimize occupational exposure in healthcare settings where exposure is possible. The use of safety devices can assist with avoiding financial penalties (up to $\$ 12,675$ per violation as of January 13, 201728) issued due to violations of the NSPA.

\section{Humanistic burden}

Nurses report that NSIs are the top concern for personal safety, followed by safety in the workplace. ${ }^{47}$ In a survey administered through the American Nurses Association to over 700 nurses in the USA regarding NSIs and workplace safety climate, $64 \%$ of nurses say NSIs and blood-borne infections remain major concerns. After NSI, most HCWs report experiencing a range of psychological effects, as depicted in Figure $3 .^{48,49,56}$ In a study of 313 HCWs postNSI, $41.8 \%$ felt anxious, depressed, or stressed following the NSI. ${ }^{71}$ In another study, anxiety was reported by $80.2 \%$ of HCWs post-NSI with $66.4 \%$ having mild/moderate anxiety, and $13.8 \%$ with persistent anxiety. ${ }^{50}$ In hospital employees who were recently evaluated for blood/body fluid exposure $(n=150), 53 \%$ reported feeling some anxiety that could be attributed to their recent exposure. ${ }^{51}$

Experiencing a NSI is significantly correlated with depressive symptoms (odds ratio 2.98), as found in a survey of medical students. ${ }^{72}$ The study by Sohn et al provides the most thorough analysis of the effects of NSI on psychological outcomes. ${ }^{53}$ In this study, psychological symptoms of 370 HCWs were assessed prior to and after NSI. The analysis showed that NSI was associated with a statistically significant increase in the Beck Depression Index $(p<0.01)$.

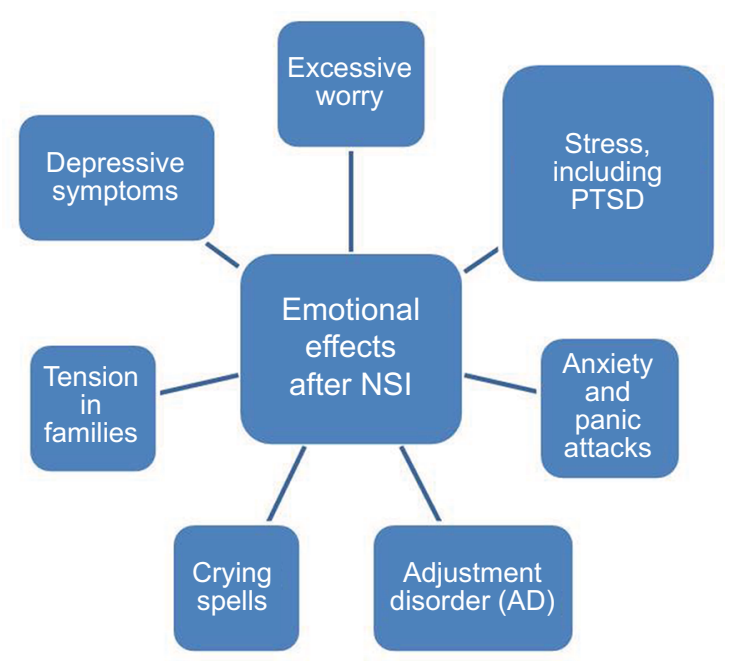

Figure 3 Humanistic impact of NSls.

Notes: Data from Green B and Griffiths EC. ${ }^{56}$

Abbreviations: NSIs, needlestick injuries; PTSD, post-traumatic stress disorder.

In addition to depression and anxiety, HCWs exposed to NSI can experience post-traumatic stress disorder (PTSD) and burnout. ${ }^{52,54,55}$ After NSI, physicians had a statistically higher likelihood of PTSD (odds ratio of 4.28) based on the Impact of Event Scale questionnaire (IES-6). ${ }^{54}$ In a study of 458 nurses, the Maslach Burnout Inventory questionnaire scores from nurses post-NSI indicated a statistically higher probability of burnout compared to unexposed nurses. ${ }^{52}$

Longer-term humanistic impact exists when NSI is from a source with known HIV disease. Even after testing negative for almost 2 years after NSI, US nurses displayed symptoms consistent with PTSD, insomnia, ongoing depression and anxiety, nightmares, and panic attacks upon returning to the work environment where the injuries were received. ${ }^{55}$

The humanistic impact and psychological effects of NSI are linked to lost productivity and work time in the USA and Europe. ${ }^{41}$ In 110 US nurses reporting lost time from NSI, 77 days of work were missed, 10 due to seeking and receiving medical attention, six due to side effects from HIV prophylactic medication, and 61 due to emotional distress and anxiety following the NSI. ${ }^{41}$ In Europe, nurses report changing their working habits/department $12.3 \%$ of time and stop working $2.4 \%$ of the time after NSI. ${ }^{20}$

\section{Gaps in the literature}

Many studies describe the impact of safety-engineered devices on overall institutional NSI rates, but do not provide sufficient detail to determine the impact of specific type of safety device used. Safety-engineered devices for hypodermic injection reduce NSI risk, but quantification of reduced disease transmission for HIV, HBV and HCV is 
unknown. Calculations of the economic burden of NSI and the economic value of safety-engineered devices have typically lacked the inclusion of indirect cost components such as cost of transportation or the cost of fear/worry, changed behavior at work and at home and pain/suffering costs. These latter costs are difficult to estimate and while it is uncertain whether these costs would significantly change the total cost of NSIs, research needs to define their importance. In addition, most articles that assessed cost of NSI acknowledged that litigation costs due to a NSI may be significant. However, no article included costs of litigation or the incidence of legal action due to NSIs.

\section{Conclusion}

Although highly preventable with proper handling and equipment, NSIs are still a significant issue among HCWs globally despite legislation in many countries. Both direct and indirect costs of NSIs are high; however, healthcare institutions can achieve cost savings and cost offsets with implementation of safety needles and devices. In addition, small studies suggest a broad range of psychological domains that are impacted in HCWs with NSI, yet comprehensive assessments are lacking. Hypodermic injection is the most common cause of NSI. The economic and humanistic burden of NSI could be reduced by implementation of safety needles for hypodermic injection (which have reduced NSIs up to $100 \%$ ), yet more must be done to enforce legislation. Future research is needed to better quantify the humanistic burden and long-term impacts of NSI for HCWs. In addition, economic studies are needed in country-specific healthcare settings to demonstrate the downstream cost offsets or cost savings of using safety needles and other safety devices for hypodermic injection.

\section{Acknowledgment}

Pharmerit International received funding from Becton Dickinson to conduct the research.

\section{Disclosure}

CEC was a consultant to Pharmerit International during the research. JMS is an employee and stockholder of Pharmerit International.

\section{References}

1. Phillips EK, Conaway MR, Jagger JC. Percutaneous injuries before and after the Needlestick Safety and Prevention Act. $N$ Engl J Med. 2012;336:670-671.

2. Trueman P, Taylor M, Twena N, Chubb B. The cost of needlestick injuries associated with insulin administration. Br J Community Nurs. 2008;13(9):413-417.
3. Leigh JP, Gillen M, Franks P, et al. Costs of needlestick injuries and subsequent hepatitis and HIV infection. Curr Med Res Opin. 2007;23(9):2093-2105.

4. Solem CT, Snedecor SJ, Khachatryan A, et al. Cost of treatment in a US commercially insured, HIV-1-infected population. PLoS One. 2014;9(5):e98152.

5. Poonsapaya JM, Einodshofer M, Kirkham HS, Glover P, DuChane J. New all oral therapy for chronic hepatitis $\mathrm{C}$ virus (HCV): a novel longterm cost comparison. Cost Eff Resour Alloc. 2015;13:17.

6. Lee TA, Veenstra DL, Hoeja UH, Sullivan SD. Cost of chronic hepatitus B infection in the United States. J Clin Gastroenterol. 2004;38(10 Suppl 3): S144-S147.

7. World Health Organization. WHO Guideline On The Use of SafetyEngineered Syringes for Intramuscular, Intradermal and Subcutaneous Injections In Health-Care Settings. Geneva, Switzerland: World Health Organization; 2015.

8. Chambers A, Mustard CA, Etches J. Trends in needlestick injury incidence following regulatory change in Ontario, Canada (2004-2012): an observational study. BMC Health Serv Res. 2015;15:127.

9. Weber T. Promotion and Support of Implementation Directive 2010/32/ $\mathrm{EU}$ on the prevention of sharps injuries in the hospital and health care sector. 2013. Available from: https://osha.europa.eu/en/legislation/directives/council-directive-2010-32-eu-prevention-from-sharp-injuries-inthe-hospital-and-healthcare-sector. Accessed April 12, 2017.

10. Khalil Sda S, Khalil OA, Lopes-Junior LC, et al. Occupational exposure to bloodborne pathogens in a specialized care service in Brazil. Am J Infect Control. 2015;43(8):e39-e41.

11. Wu HC, Ho JJ, Lin MH, Chen CJ, Guo YL, Shiao JS. Incidence of percutaneous injury in Taiwan healthcare workers. Epidemiol Infect. 2015;143(15):3308-3315.

12. Phillips EK, Conaway M, Parker G, Perry J, Jagger J. Issues in understanding the impact of the Needlestick Safety and Prevention Act on hospital sharps injuries. Infect Control Hosp Epidemiol. 2013;34(9):935-939.

13. Jagger J, Perry J, Gomaa A, Phillips EK. The impact of U.S. policies to protect healthcare workers from bloodborne pathogens: the critical role of safety-engineered devices. J Infect Public Health. 2008;1(2):62-71.

14. MindMetre. Safer sharps: a barometer of take-up in the UK. 2014. Available from: http://www.mindmetreresearch.com/wp-content/ uploads/2014/02/Safer-sharps_A-barometer-of-take-up-in-the-UK_ report.pdf. Accessed December 14, 2016.

15. Nkoko L, Spiegel J, Rau A, Yassi A. Reducing the risks to health care workers from blood and body fluid exposure in a small rural hospital in ThaboMofutsanyana, South Africa. Workplace Health Saf. 2014;62(9):382-388.

16. Talaat M, Kandeel A, El-Shoubary W, et al. Occupational exposure to needlestick injuries and hepatitis B vaccination coverage among health care workers in Egypt. Am J Infect Control. 2003;31(8):469-474.

17. Memish ZA, Assiri AM, Eldalatony MM, Hathout HM. Benchmarking of percutaneous injuries at the Ministry of Health hospitals of Saudi Arabia in comparison with the United States hospitals participating in Exposure Prevention Information Network (EPINet). Int J Occup Environ Med. 2015;6(1):26-33.

18. EPINet. EPINet Report for Needlestick and Sharp Object Injuries. International Safety Center. Available from: https://internationalsafetycenter. org/wp-content/uploads/2016/08/Official-2014-NeedleSummary.pdf. Accessed April 12, 2017.

19. Balkhy HH, El Beltagy KE, El-Saed A, Sallah M, Jagger J. Benchmarking of percutaneous injuries at a teaching tertiary care center in Saudi Arabia relative to United States hospitals participating in the Exposure Prevention Information Network. Am J Infect Control. 2011;39(7):560-565.

20. Costigliola V, Frid A, Letondeur C, Strauss K. Needlestick injuries in European nurses in diabetes. Diabetes Metab. 2012;38(Suppl 1):S9-S14.

21. The National Institute for Occupational Safety and Health (NIOSH). Stop Sticks Campaign. Available from: https://www.cdc.gov/niosh/ stopsticks/default.html. Accessed April 12, 2017.

22. Voide C, Darling KE, Kenfak-Foguena A, Erard V, Cavassini M, LazorBlanchet C. Underreporting of needlestick and sharps injuries among healthcare workers in a Swiss University Hospital. Swiss Med Wkly. 2012;142:w13523. 
23. Hanmore E, Maclaine G, Garin F, Alonso A, Leroy N, Ruff L. Economic benefits of safety-engineered sharp devices in Belgium - a budget impact model. BMC Health Serv Res. 2013;13:489.

24. Afridi AA, Kumar A, Sayani R. Needle stick injuries risk and preventive factors: a study among health care workers in tertiary care hospitals in Pakistan. Glob J Health Sci. 2013;5(4):85-92

25. Chalya PL, Seni J, Mushi MF, et al. Needle-stick injuries and splash exposures among health-care workers at a tertiary care hospital in north-western Tanzania. Tanzan J Health Res. 2015;17(2):1-15.

26. Gillen M, McNary J, Lewis J, et al. Sharps-related injuries in California healthcare facilities: pilot study results from the sharps injury surveillance registry. Infect Control Hosp Epidemiol. 2003;24(2):113-121.

27. Wilson SP, Miller J, Mahan M, Krupp S. The Urban Emergency Department: a potential increased occupational hazard for sharps-related injuries. Acad Emerg Med. 2015;22(11):1348-1350.

28. Occupational Safety and Health Administration. OSHA penalties as of January 13, 2017. Available from: https://www.osha.gov/penalties/. Accessed August 21, 2017.

29. Wittmann A, Hofmann F, Kralj N. Needle stick injuries - Risk from blood contact in dialysis. J Ren Care. 2007;33(2):70-73.

30. Napoli VM, McGowan JE Jr. How much blood is in a needlestick?. J Infect Dis. 1987;155(4):828.

31. Simonsen L, Kane A, Lloyd J, Zaffran M, Kane M. Unsafe injections in the developing world and transmission of bloodborne pathogens: a review. Bull World Health Organ. 1999;77(10):789-800.

32. The Centers for Disease Control and Prevention. The National Surveillance System for Healthcare Workers $(\mathrm{NaSH})$ : summary report for blood and body fluid exposure data collected from participating healthcare facilities (June 1995 through December 2007). 2011. Available from: https://www.cdc.gov/nhsn/pdfs/nash/nash-report-6-2011.pdf. Accessed April 12, 2017.

33. Jagger J, Berguer R, Phillips EK, Parker G, Gomaa AE. Increase in sharps injuries in surgical settings versus nonsurgical settings after passage of national needlestick legislation. J Am Coll Surg. 2010;210(4):496-502.

34. Tuma S, Sepkowitz KA. Efficacy of safety-engineered device implementation in the prevention of percutaneous injuries: a review of published studies. Clin Infect Dis. 2006;42(8):1159-1170.

35. Harb AC, Tarabay R, Diab B, Ballout RA, Khamassi S, Aki EA. Safety engineered injection devices for intramuscular, subcutaneous, and intradermal injections in healthcare delivery settings: a systematic review and meta-analysis. BMC Nurs. 2015;14:71.

36. Zakrzewska JM, Greenwood I, Jackson J. Introducing safety syringes into a UK dental school a controlled study. Br Dent J. 2001;190(2): 88-92.

37. Adams D, Elliott TS. Impact of safety needle devices on occupationally acquired needlestick injuries: a four-year prospective study. $J$ Hosp Infect. 2006;64(1):50-55.

38. van der Molen HF, Zwinderman KAH, Sluiter JK, Frings-Dresen MHW. Better effect of the use of a needle safety device in combination with an interactive workshop to prevent needle stick injuries. Safety Science. 2011;49(8-9):1180-1186.

39. Valls V, Lozano MS, Yánez R, et al. Use of safety devices and the prevention of percutaneous injuries among healthcare workers. Infect Control Hosp Epidemiol. 2007;28(12):1352-1360.

40. The Centers for Disease Control and Prevention. Implementing and evaluating a Sharps Injury Prevention Program. 2008. Available from: http://www.cdc.gov/sharpssafety/pdf/sharpsworkbook_2008.pdf. Accessed April 12, 2017.

41. Lee WC, Nicklasson L, Cobden D, Chen E, Conway D, Pashos CL. Short-term economic impact associated with occupational needlestick injuries among acute care nurses. Curr Med Res Opin. 2005;21(12): 1915-1922.

42. Whitby M, McLaws ML, Slater K. Needlestick injuries in a major teaching hospital: the worthwhile effect of hospital-wide replacement of conventional hollow-bore needles. Am J Infect Control. 2008;36(3):180-186.
43. Oh HS, Yoon Chang SW, Choi JS, Park ES, Jin HY. Costs of postexposure management of occupational sharps injuries in health care workers in the Republic of Korea. Am J Infect Control. 2013;41(1):61-65.

44. Glenngard AH, Persson U. Costs associated with sharps injuries in the Swedish health care setting and potential cost savings from needlestick prevention devices with needle and syringe. Scand J Infect Dis. 2009;41(4):296-302.

45. Lee JM, Botteman MF, Xanthakos N, Nicklasson L. Needlestick injuries in the United States. Epidemiologic, economic, and quality of life issues. AAOHN J. 2005;53(3):117-133.

46. California Occupational Safety and Health Administration. Bloodborne pathogens. 8. California Code of Regulations1998. Available from: https://www.dir.ca.gov/title8/5193.html. Accessed April 12, 2017.

47. McNamara M, Patterson D. Workplace Safety And Needlestick Injuries Are Top Concerns For Nurses. www.nursingworld.org: American Nurses Association; 2008:1-4. Available from: http://www.nursingworld.org/ MainMenuCategories/WorkplaceSafety/Healthy-Work-Environment/ SafeNeedles/Press/WorkplaceSafetyTopConcerns.pdf. Accessed April 12, 2017.

48. Wright D. Hepatitis C nightmare. Interview by Charlotte Alderman. Nurs Stand 2005;20:26-27.

49. Seibert C. Stuck. Ann Intern Med. 2003;138(9):765-766.

50. Wicker S, Stirn AV, Rabenau HF, von Gierke L, Wutzler S, Stephan C. Needlestick injuries: causes, preventability and psychological impact. Infection. 2014;42(3):549-552.

51. Gershon RR, Flanagan PA, Karkashian C, et al. Health care workers' experience with postexposure management of bloodborne pathogen exposures: a pilot study. Am J Infect Control. 2000;28(6):421-428.

52. Wang S, Yao L, Li S, Liu Y, Wang H, Sun Y. Sharps injuries and job burnout: a cross-sectional study among nurses in China. Nurs Health Sci. 2012;14(3):332-338.

53. Sohn JW, Kim BG, Kim SH, Han C. Mental health of healthcare workers who experience needlestick and sharps injuries. J Occup Health. 2006;48(6):474-479.

54. Naghavi SH, Shabestari O, Alcolado J. Post-traumatic stress disorder in trainee doctors with previous needlestick injuries. Occup Med (Lond). 2013;63(4):260-265.

55. Worthington MG, Ross JJ, Bergeron EK. Posttraumatic stress disorder after occupational HIV exposure: two cases and a literature review. Infect Control Hosp Epidemiol. 2006;27(2):215-217.

56. Green B, Griffiths EC. Psychiatric consequences of needlestick injury. Occup Med (Lond). 2013;63(3):183-188.

57. The Australian Council on Healthcare Standards. Infection Control version 3.1. Retrospective Data In Full. 13th ed. Sydney, NSW: ACHS; 2012.

58. Marziale MH, Rocha FL, Robazzi ML, Cenzi CM, dos Santos HE, Trovo ME. Organizational influence on the occurrence of work accidents involving exposure to biological material. Rev Lat Am Enfermagem. 2013;21 Spec No:199-206.

59. Zhang X, Gu Y, Cui M, Stallones L, Xiang H. Needlestick and sharps injuries among nurses at a teaching hospital in China. Workplace Health Saf. 2015;63(5):219-225.

60. Floret N, Ali-Brandmeyer O, L'Hériteau F, et al. Sharp decrease of reported occupational blood and body fluid exposures in French hospitals, 2003-2012: results of the French National Network Survey, AES-RAISIN. Infect Control Hosp Epidemiol. 2015;36(8): 963-968.

61. Stefanati A, Boschetto P, Previato S, et al. [A survey on injuries among nurses and nursing students: a descriptive epidemiologic analysis between 2002 and 2012 at a University Hospital]. Med Lav. 2015;106(3):216-229. Italian.

62. Frijstein G, Hortensius J, Zaaijer HL. Needlestick injuries and infectious patients in a major academic medical centre from 2003 to 2010. Neth J Med. 2011;69(10):465-468.

63. Oh HS, Yi SE, Choe KW. Epidemiological characteristics of occupational blood exposures of healthcare workers in a university hospital in South Korea for 10 years. J Hosp Infect. 2005;60(3):269-275. 
64. Shiao JS, Lin MS, Shih TS, Jagger J, Chen CJ. National incidence of percutaneous injury in Taiwan healthcare workers. Res Nurs Health. 2008;31(2):172-179.

65. Royal College of Nursing. Needlestick injury in 2008: results from a survey of RCN members. 2008. Available from: https://www.ren.org. uk/professional-development/publications/pub-003304. Accessed April 12, 2017.

66. Van der Molen HF, Zwinderman KA, Sluiter JK, Frings-Dresen MH. Interventions to prevent needle stick injuries among health care workers. Work. 2012;41(Suppl 1):1969-1971.

67. Mannocci A, De Carli G, Di Bari V, et al. How much do needlestick injuries cost? A systematic review of the economic evaluations of needlestick and sharps injuries among healthcare personnel. Infect Control Hosp Epidemiol. 2016;37(6):635-646.

68. O’Malley EM, Scott RD 2nd, Gayle J, et al. Costs of management of occupational exposures to blood and body fluids. Infect Control Hosp Epidemiol. 2007;28(7):774-782.
69. Burrows LA, Padkin A. A survey of the management of needlestick injuries from incapacitated patients in intensive care units. Anaesthesia. 2010;65(9):880-884

70. Tosini W, Ciotti C, Goyer F, Lolom I, L'Hériteau F, Abiteboul D, Pellissier G, Bouvet E. Needlestick injury rates according to different types of safety-engineered devices: results of a French multicenter study. Infect Control Hosp Epidemiol. 2010;31(4):402-407.

71. Lee JM, Botteman MF, Nicklasson L, Cobden D, Pashos CL. Needlestick injury in acute care nurses caring for patients with diabetes mellitus: a retrospective study. Curr Med Res Opin. 2005;21(5):741-747.

72. Wada K, Sakata Y, Fujino Y, et al. The association of needlestick injury with depressive symptoms among first-year medical residents in Japan. Ind Health. 2007;45(6):75-755. 


\section{Supplementary material}

Table SI Search terms used in PubMed

\begin{tabular}{|c|c|}
\hline Subject area & Search terms \\
\hline Needlestick injury & (Needlestick injury[Mesh] OR “Accidental needle stick”) AND \\
\hline \multirow[t]{3}{*}{ Safety needles } & (“Safety needles” OR “Safety-engineered needles” OR “Engineered-sharps” OR “Needleless systems” OR \\
\hline & (Needles[majr] AND (Device safety[Mesh] OR “Safety-engineered devices” OR Passive[Title/Abstract] OR \\
\hline & Mechanism[Title/Abstract])) OR \\
\hline Clinical burden & Viral infection[Mesh] OR Hepatitis C[Mesh] OR HIV[Mesh] OR Hepatitis B[Mesh] OR \\
\hline \multirow[t]{2}{*}{ Quality of life/utilities } & "Quality of life” OR QoL OR HRQoL OR "health related quality of life” OR Utility OR Utilities OR Patient \\
\hline & satisfaction[Mesh] OR Worry OR Distress OR \\
\hline Resource utilization/costs & "Resource utilization" OR "Resource use" OR Cost OR Costs OR "Cost analysis" OR "Budget impact" OR \\
\hline Indirect costs & "Indirect costs” OR Productivity OR “Work loss” OR “Work policy” OR \\
\hline Policy & Policy[Title/Abstract] OR Public policy[Mesh]) \\
\hline
\end{tabular}

Abbreviation: HIV, human immunodeficiency virus.

\section{Publish your work in this journal}

Medical Devices: Evidence and Research is an international, peerreviewed, open access journal that focuses on the evidence, technology, research, and expert opinion supporting the use and application of medical devices in the diagnosis, monitoring, treatment and management of clinical conditions and physiological processes. The identification of novel devices and optimal use of existing devices which will lead to improved clinical outcomes and more effective patient management and safety is a key feature. The manuscript management system is completely online and includes a quick and fair peer-review system. Visit http://www. dovepress.com/testimonials.php to read real quotes from authors.

Submit your manuscript here: https://www.dovepress.com/medical-devices-evidence-and-research-journal 